جداسازى و شناسايى باسيلوس مولد آلفآميلاز كرمادوست: بهينهازى توليد و بررسى

\author{
فعاليت و يايدارى دمايى \\ سعيده افريشم، ارسطو بدويى دلفارد"، عبدالحميد نمكى شوشترى، زهرا كرمى و سعيد ملكك آبادى \\ دريافت:
}

كروه زيستشناسى، دانشكدة علوم، دانشكاه شهيد باهنر كرمان، كرمان، ايران

badoei@uk.ac.ir :نويسنده مسئول:

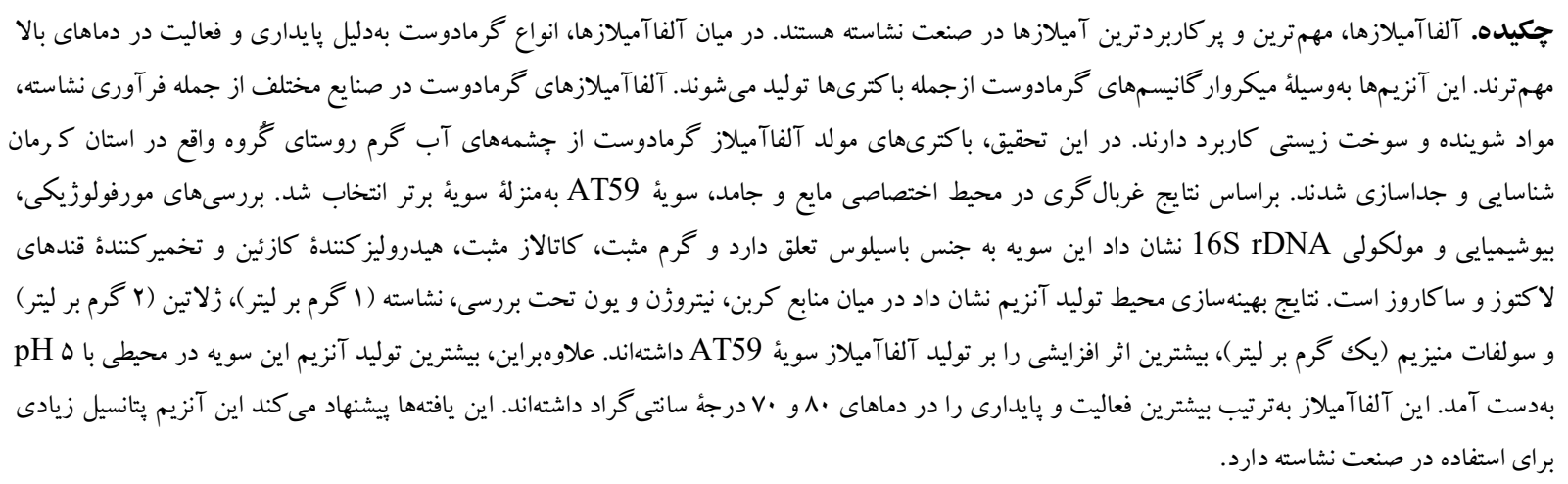

وازههاى كليدى. آنزيمهاى گرمادوست، توليد، جشمه آب گرم، غربال گرى

\title{
Isolation and identification of Bacillus producing thermophilic alpha amylase: production optimization and investigation of the activity and stability of enzyme
}

\author{
Saideh Afrisham, Arastoo Badoei-Dalfard*, Abdolhamid Namaki-Shoushtari, Zahra Karami \& \\ Saeid Malekabadi \\ Received 19.08.2016/ Accepted 04.12.2017/ Published 19.03.2018
}

Department of Biology, Faculty of Sciences, Shahid Bahonar University of Kerman, Kerman, Iran

*Correspondent author: badoei@uk.ac.ir

\begin{abstract}
Alpha-amylases are the most important amylases used in industry. Among them, thermophilic alphaamylases are of particular importance, which is due to their activity and stability in high temperatures. These enzymes produced by thermophile micro-organisms including bacteria. These thermophilic alpha-amylases are used in various industries such as processing of starch as well as production of detergents and biofuels. In this research, the bacteria which produce the thermophilic alpha-amylases were isolated and characterized in hot springs of Gorooh village in Kerman province. According to the results of screening on the specific liquid and solid media, AT59 was selected as the best strain. Morphological and biochemical characterization of the isolated strain indicated that it belonged to Bacillus sp. and was gram-positive, catalase positive, casein hydrolyzing and acid producing from lactose and sucrose. The results obtained from the optimization of the enzyme production medium showed that among the carbon, nitrogen and ion sources investigated, starch $(1 \mathrm{gr} / \mathrm{l})$, gelatin $(2 \mathrm{~g} / \mathrm{l})$ and magnesium sulfate $(1 \mathrm{~g} / \mathrm{l})$ had the most increasing effect on the production of AT59 alpha-amylase. Moreover, the highest enzyme production was obtained at pH 5. This enzyme also demonstrated the highest degree of activity and stability in 80 and $70{ }^{\circ} \mathrm{C}$, respectively. These findings suggested that this enzyme has a considerable potential for use in starch industry.
\end{abstract}

Keywords. hot spring, production, screening, thermophilic enzymes 
محيط كشت ازجمله منابع كربن و نيتروزن، مو اد معلنى و همجنين

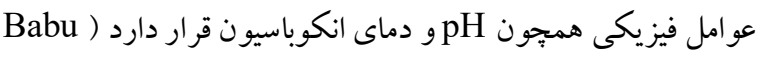
\& Satyanarayana, 1995 مزوفيل و حتى سرمادوست، مطالعات كمترى درباره جداسازى و غربالكرى سويههاى گرمادوست، محيط رشدشان و نيز بهينهسازى نـ توليد آنزيم آنها صورت گرفته است (Asgher et al., 2007). هدف اين مطالعه جداسازى و شناسايى سويههاى باكتريايى

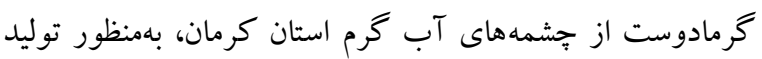

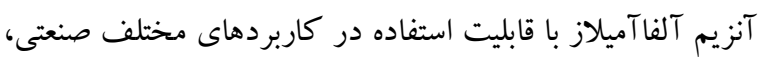
بوده است. در اين مطالعه شرايط بهينه براى توليد آنزيم بهدستآمده نيز تعيين شد.

\section{مواد و روشها

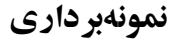

در اين تحقيق، جشمههاى آبَّرم روستاى گُروه از توابع بخش جبالبارز شهرستان جيرفت در استان كرمان جهت نمونهبردارى انتخاب شدند. نمونهاى آب و رسويات از دو جشمه موجود در

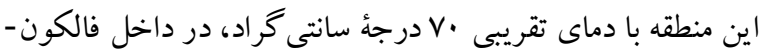

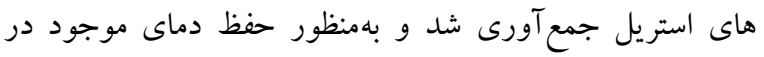
جشمهها، فالكو نها در داخل فلاسك به به آزمايشكاه منتقل شدند. جداسازى و غربال كرى سويههاى باكتريايى مولد آلفا آميلاز بهمنظور جداسازى سويههاى باكتريايى با توانايى هيدروليز

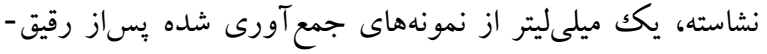
سازى متوالى به محيطهاى نشاسته آكار حاوى يككدرصد نشاسته

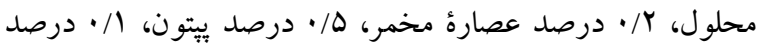

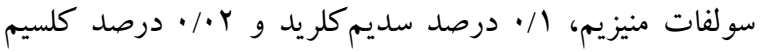
كلريد و 1/ه درصد آكار تلقيح و اين محيطها Vr ساعت در

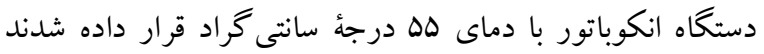
(Oziengbe \& Onilude, 2012) كلنىهاى رشديافته روى اين محيطها انتخاب و مجدداً روى محيط نشاسته Tكار كشت داده شدند و Vr ساعت در ها هـ درجة

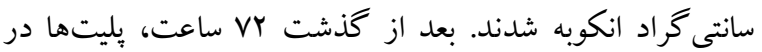
محلول لو گول غوطهور شدند و كلنىهاى داراى هاله شفاف به

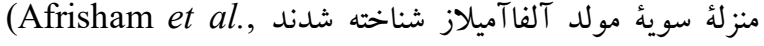
-2016; Ahmadi et al., 2010)
مقلدمه

ميكروار گانيسمهاى گرمادوست موجوداتى هستند كه با رشد

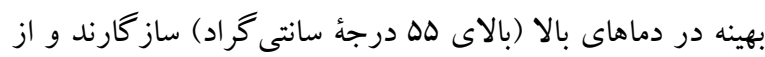

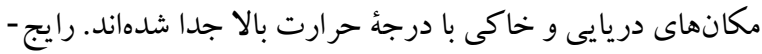

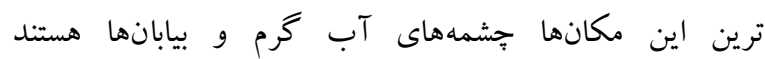
Antranikian \& Egorova, 2007) كرمادوست منبعى از آنزيمهايى شناخته مىشوند كه هم از نظر شيميايى و هم از نظر فيزيولوزيكى مقاومت بالايى نشان داده (Haki \& Rakshit, 2003) دماهاى بالاترى نسبت به آنزيمهاى ميكروار كانيسمهاى مزوفيل

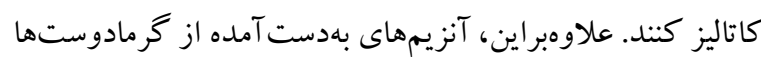

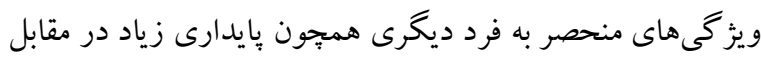

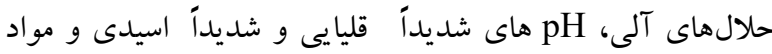

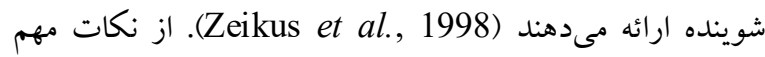
دربارهٔ ميكروار كانيسمهاى گرمادوست توانايى توليد آنزيمهاى آميلوليتيك گرمادوست با كارايى بالا است كه در فر آورى نشاسته و توليد قند، صنعت نساجى و همجِين مواد شوينده كاربرد دارند (Abdel-Fattah et al., 2012) و مهمترين آميلازهاى صنعتى هستند كه بهطور تصادفى بيوند

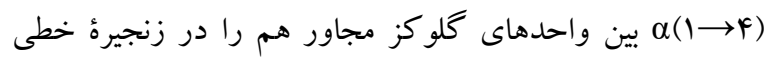

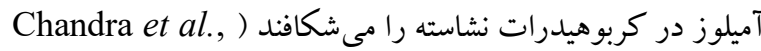

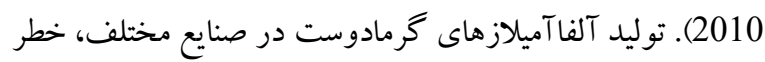

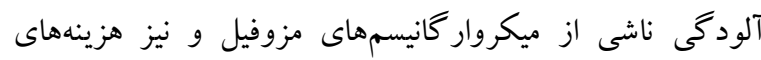
سردكردن اضافى را كاهش مىدهد و بهطور ويزه در صنعت فر آورى نشاسته، افزايش در ضريب انتشار سوبسترا، حلاليت بهتر

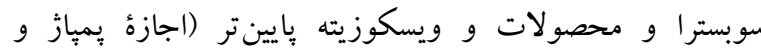

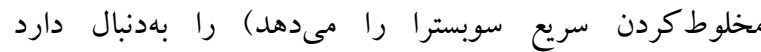

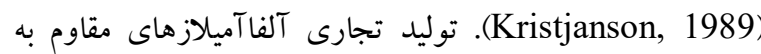
كرما بهطور گسترده بهوسيلة اعضاى جنس باسيلوس ازجمله ،Bacillus stearothermophilus ،Bacillus subtilis Bacillus amyloliquefaciens, Bacillus licheniformis صورت گرفته است (Souza, 2010). با توجه به اهميت صنعتى

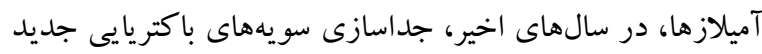

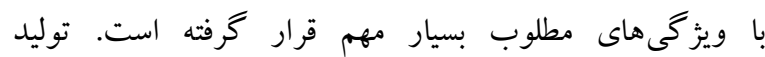
آلفآميلازهاى ميكروبى به ميزان زيادى تحت تأثير تركيبات 
بايكاه اطلاعاتى Gene Bank به كمك نرمافزار MEGA4 با روش neighbor joining ترسيم شد (Tamura et al., 2007). محيط توليد آنزيم در ابتدا، يكك لوبِ پِر از كلنى باكترى مورد نظر به •r ميلىليتر

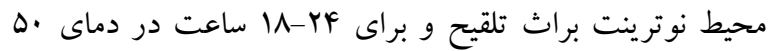

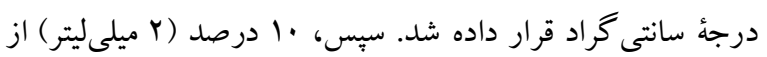
محيط كشت MF-MF ساعته به محيط توليد حاوى يكك گرم نشاسته،

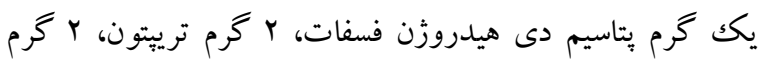

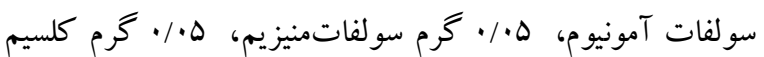

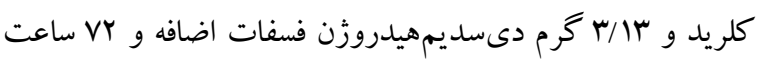

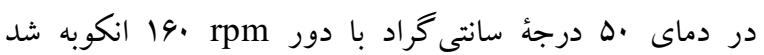
.(Samie et al., 2012)

\section{رسم منحنى استاندارد كلوكز}

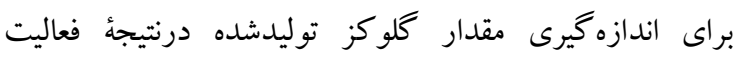

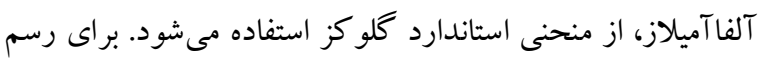

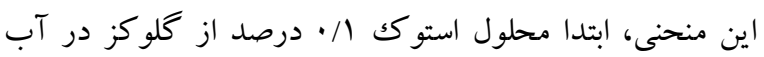

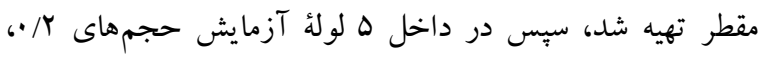

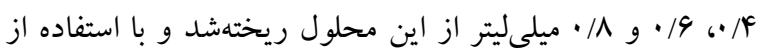

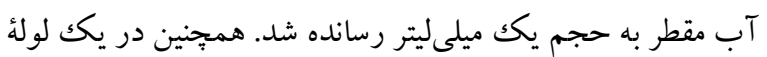

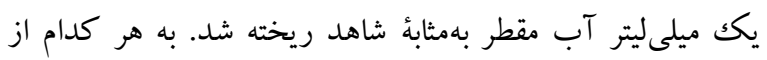

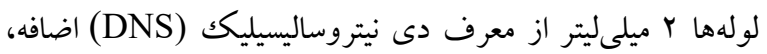

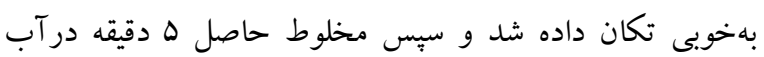
جوش قرار گرفت. پس از سردشدن محتواى لولهها در دماى اتاق،

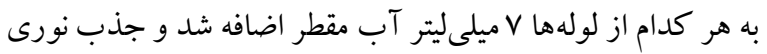

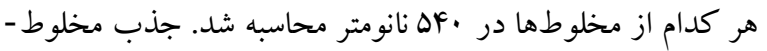
هاى حاوى كلوكز از جذب نمونة شاهد كم شد و دور درنهايت،

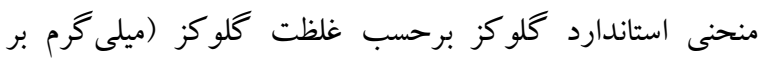

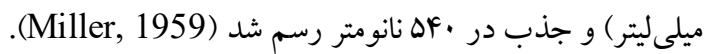
سنجش فعاليت آلفاآميلاز بهمنظور تأييد خاصيت هيدروليز كند كَى نشاسته و تعيين ميزان توليد آنزيم آلفآميلاز، سنجش فعاليت آنزيم آلفآميلاز براساس

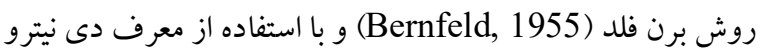

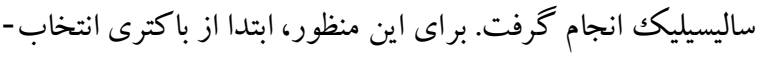

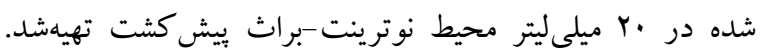

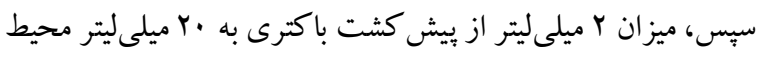

هاى جداشده، سوية AT59 براساس قطر هاله ناشى از هيدروليز نشاسته بهمثابه سويةٌ برتر انتخاب و جهت مطالعات آنزيمى استفاده

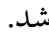
شناسايى سويؤ باكتريايى جداشده بهنظور شناسايى نسبى سويههاى جدا شده، تعدادى از آزمون -

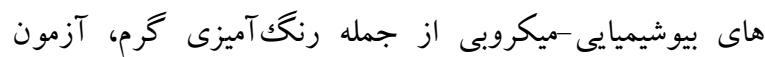
KOH

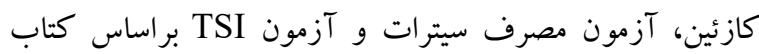

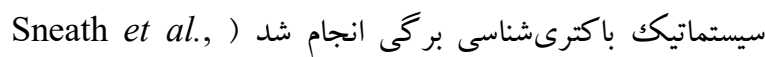

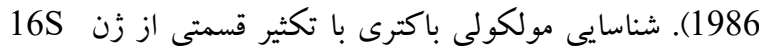
Forward: 5'-AGTTTGATCC- توسط برايمرهاى توني

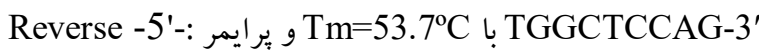
$\mathrm{Tm}=53.4{ }^{\circ} \mathrm{C}$ GGCTACCTTGTTACGACTT- 3' انجام شد (Badoei-Dalfard et al., 2016). واكنش زنجيرهاى يليمراز (PCR)، در حجم نهايى فا ميكروليتر، شامل r ميكروليتر

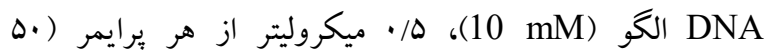

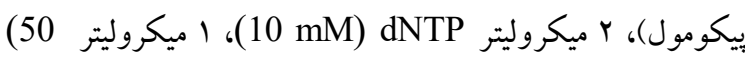

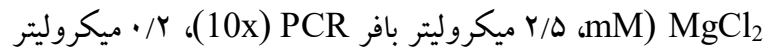
آنزيم 5u/ml) Taq DNA Polymerase) خريدارىشده از شركت سينازن و 19// ميكروليتر آب مقطر ديونيزه با برنامة ذيل انجام شد (Badoei-Dalfard et al., 2016): () دماى اوليه

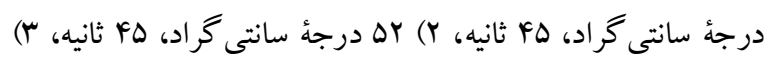

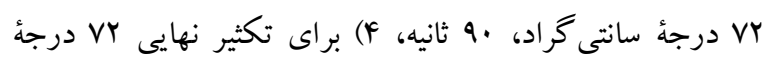

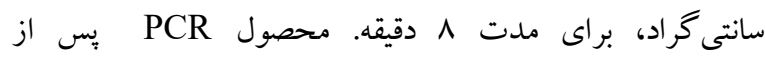
الكتروفورز زل آكارز يككدرصد با استفاده از كيت استخراج

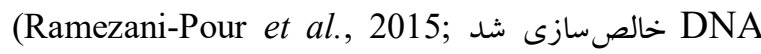
(Azadian et al., 2016) توالىياب DNA شركت Bioneer، واقع در كره جنوبى تعيين شد. شباهت توالى نو كلئوتيدهاى زُن 16S rDN سوئ هيدروليز كنده به كمك نرمافزار BLAST با تو الىهاى ثبتشده

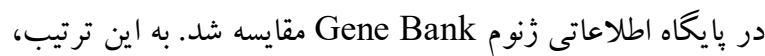
نزديككترين سويهها با ترادف 16S rDNA با سويه تعيين شد.

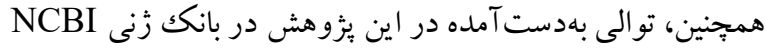

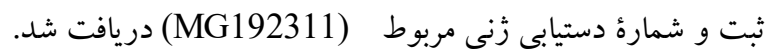
درخت فيلوزنى توالى سويه با توالى حاصل از جستوجو در 
در اين بررسى، ·ل درصد از ييش كشت MF-YY ساعته باكترى

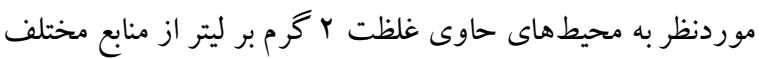

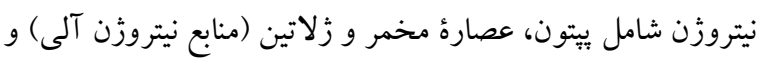
آمونيوم كلرايد، سولفات آمونيوم و سديم نيترات (منبع نيتروزن غير آلى) و محيط بدون منبع اضافه شد ( Ramachandran et al.,

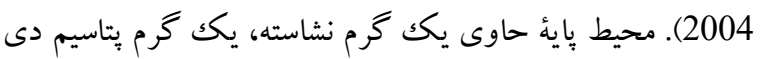
هيدروزن فسفات، ه •/ • گرم سولفات منيزيم، ه •/ • گرم كلسيمكلريد و باس گرم دىسديم هيدروزن فسفات بهازاى يكك ليتر آب مقطر بود. محيطها AN ساعت در دماى •ه درجة سانتى گراد انكوبه شدند. يس از FA ساعت، ه ميلى ليتر از محيطها سانتريفيوز شP. شا و سنجش فعاليت آنزيمى محلولهاى رويى در طولموج نانومتر انجام كرفت. سبس، محلولهاى رويى دور ريخته شدند و وزن رسوبات باكتريايى اندازه كيرى شد. توليد آنزيم در حضور تر كيبات يونى مختلف براى بررسى اثر يونهاى فلزى مختلف بر توليد آنزيم، غلظت يكك كرم بر ليتر از يتاسيم كلريد، سديم كلريد، كلسيم كلريد و سولفاتمنيزيم به محيط كشت بدون يون فلزى اضافهد

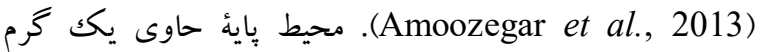
نشاسته، Y گرم تريبتون بهازاى يك ليتر آبمقطر بود. بعداز ساعت، انكوياسيون در دماى •ه درجة سانتى گراد، ه ميلىليتر از هر كدام از محيطهاى حاوى باكترى رشديافته سانتريفيوزشده و مايع رويى بلمنظور سنجش فعاليت آنزيمى مورد استفاده قرار كرفت. همجنين، وزن تر رسوبات باكتريايى بهدست آمده اندازهـ كيرى شد.

\section{بروسى اثر pH بر توليد آنزيم آلفآميلاز} اثر pH بر توليد آنزيم آلفآميلاز، با تنظيم pH محيط مايع Aullybux \& ( اختصاصى در محدودة 9-ه سنجيده شد

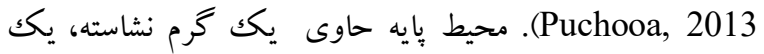

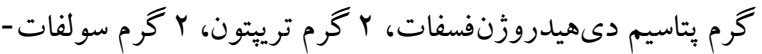

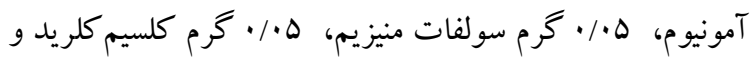
س/ گ گرم دىسديمهيدروزن فسفات بهازاى يكك ليتر آب مقطر

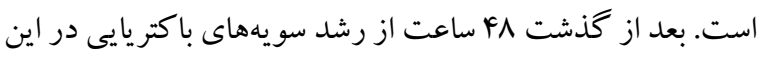
محيطها، ه ميلى ليتر از محيطها سانتريفيوز شد و فعاليت آنزيمى مايع سنجش شد و وزن تر رسوبات باكتريايى نيز اندازه بررسى فعاليت دمايى آنزيم آلفآميلاز
توليد تلقيح و VY ساعت در انكوباتور با دماى •ه درجة سانتى - له كراد انكوبه شد. ه ميلىليتر از محيط حاوى باكترى برداشته شد و

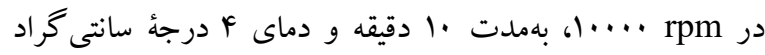
سانتريفيوز شد. محلول رويى فاقد باكترى بهمثابة آنزيم مورد استفاده قراركرفت. سبس، . .ه ميلىليتر از محلول رويى به . ..ه ميكروليتر نشاسته يككدرصد محلول در بافر سديم فسفات

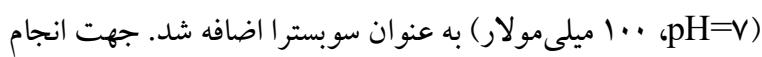
واكنش، مخلوط حاصل در •ه درجة سانتى كراد به مدت ·r دقيقه كرماكذارى شد. در مرحلهُ بعد، واكنش آنزيماتيك با اضافه كردن يكك ميلىليتر از DNS به مخلوط و قراردادن آن به مدت هـ دقيقه در آب جوش بايان يافت. اين وضعيت بهمثابه وضعيت استاندارد در نظر كرفته شد. با استفاده از منحنى استاندارد گكلوكز غلظت ئل قندهاى احياكننده توليدشده درنتيجهُ فعاليت آنزيم آلفآميلاز محاسبه شد و به اين تر تيب مقدار فعاليت آنزيمى بهدست آمد. بر اين اساس، يكك واحد فعاليت آنزيمى مقدار آنزيمى است كه در يكك دقيقه، يكك ميكرومول سوبسترا را به يكك ميكرومول محصول

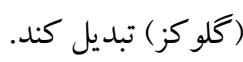

بررسى توليد آنزيم آلفآميلاز در حضور متغيرهاى مختلف اثر منابع مختلف كربن بر توليد آنزيم آلفآيلاز براى شناسايى منبع كربن مناسب براى توليد آنزيم آلفآميلاز، سوية باكترى جداشده در حضور منابع باكتريايى مختلف كربن شامل كلوكز، كالاكتوز، مالتوز، فروكتوز و نشاسته هركدام در

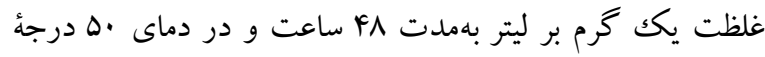
سانتى گراد كشت داده شد (Amoozegar et al., 2013 (A). محيط يايه حاوى يكك گرم يتاسيم دىهيدروزن فسفات، ب گرم ترييتون،

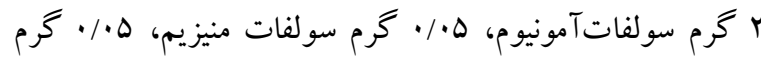
كلسيم كلريد و سا/ كرم دىسديم هيدروزن فسفات بهازاى يكك ليتر آب مقطر بود. بعد از اين مدت، ه ميلىليتر از اين محيطها در أ.rpm سانتريفيوز شده و محلولهاى رويى بهمنزله آنزيم مورد استفاده قرار گرفت. سنجش فعاليت آنزيمى مطابق با شرايط استاندارد در نF. نانومتر صورت كرفت. وزن تر رسوب باكترىها برحسب ميلى گرم بر ميلىليتر، بهمنزلهُ معيارى از ميزان رشد اندازه گيرى شد. تمامى آزمايشها سه بار تكرار شد و ميانكين گرفته شد. اثر منابع مختلف نيتروزن بر توليد آنزيم آلفآميلاز 
اثر منابع مختلف كربن بر توليد آنزيم آلفآميلاز

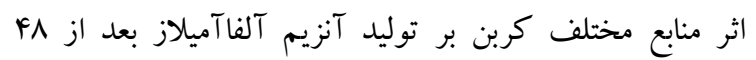
ساعت انكوباسيون تحت بررسى قرار گرفت و مشخص شد توني توليد

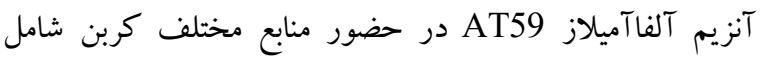

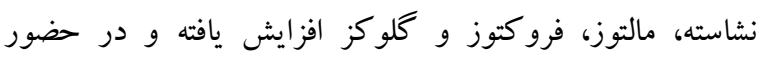

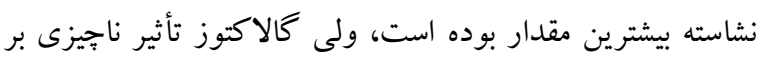

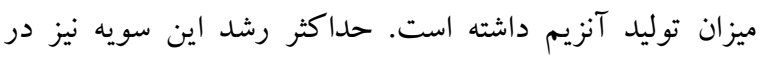

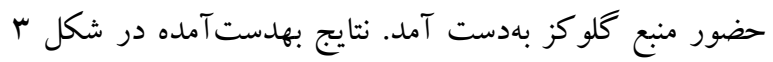
نشان داده شده است.

\section{اثر منابع مختلف نيتروزن بر توليد آنزيم آلفآميلاز}

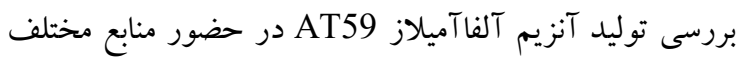
نيتروزن شامل ييتون، عصاره مخمر، زلاتين، آمونيومكلرايد،

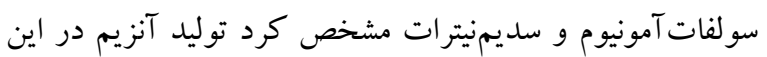
سويه در حضور اكثر منابع نيتروزنى افزايش يافته است و زلاتين

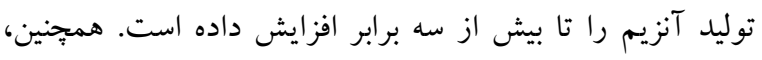

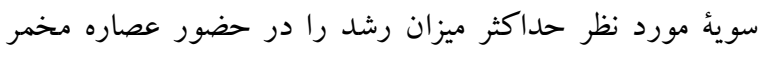
نشان داد. نتايج كفتهشده در شكل F ع آمده است.

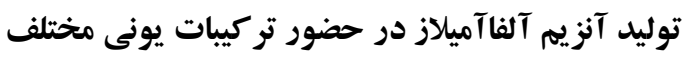

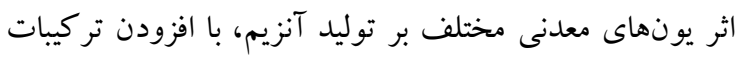
يونى مختلف شامل يتاسيم كلريد، سولفاتمنيزيم، سديم كلريد و

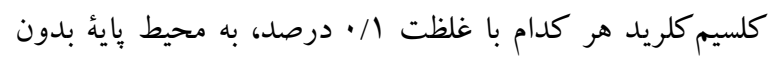

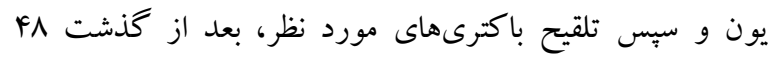

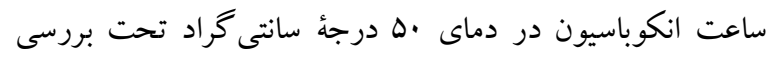

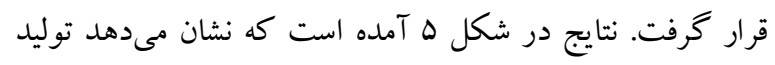

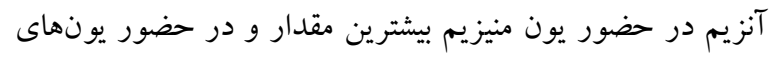

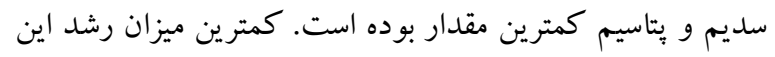

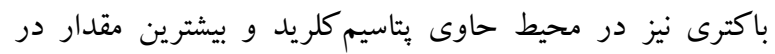
حضور كلريدسديم مشاهده شد.

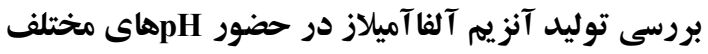

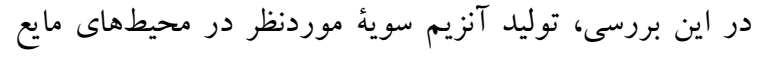

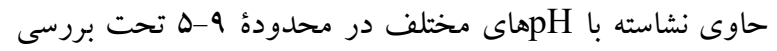

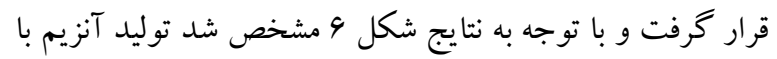

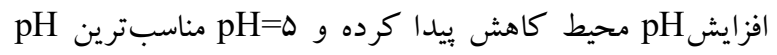

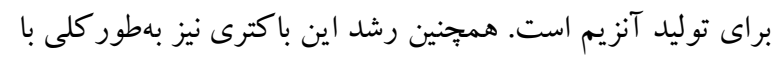

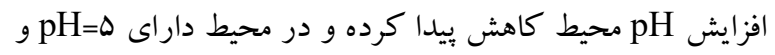

براى بررسى فعاليت دمايى آنزيم آلفآميلاز، مخلوط ه/· ميلى-

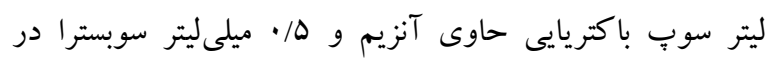

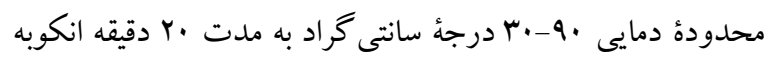

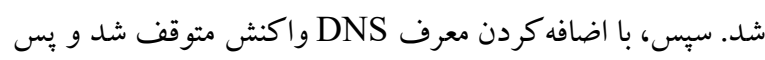
از قراردادن مخلوط واكنش در دستگاه بنمارى به مدت هـ هـ دقيقه، جذب مخلوط در م ه نانومتر خو انش شد. فعاليت باقى مانده آنزيم بهورت درصد محاسبه شد (Prakash et al., 2009). بررسى پايدارى دمايى آنزيم آلفآميلاز

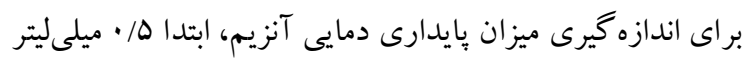

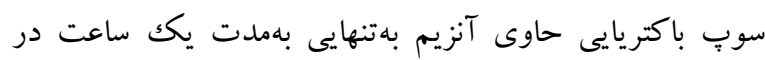

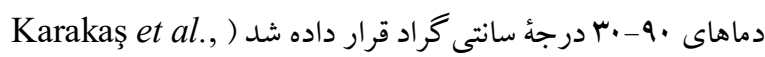

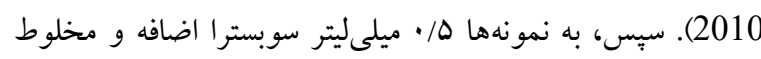
حاصل در شر ايط سنجش انكوبه شد. درنهايت، فعاليت باقىمانده

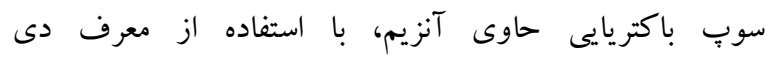

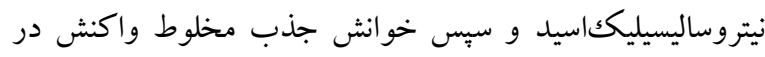

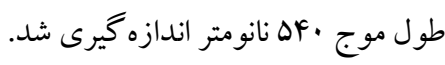

\section{تتايج}

\section{غربال كرى و شناسايع سويههاى باكتريايى مولد آلفاآميلاز}

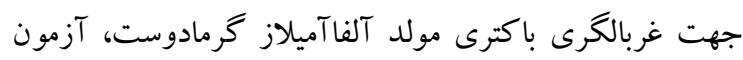

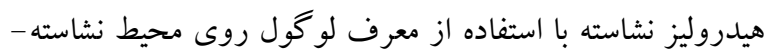
آكار انجام گرفت و هاله شفاف اطراف كلنى باكترى، كه نشان-

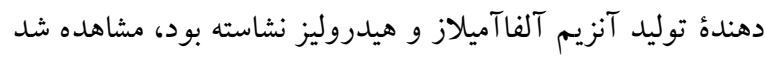

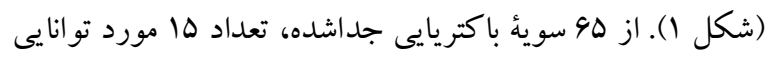

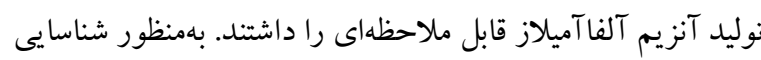

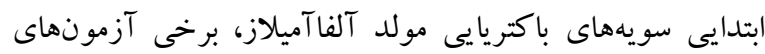

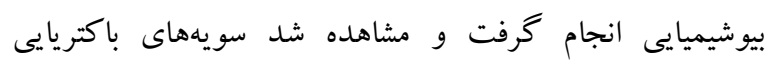

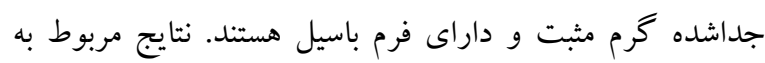

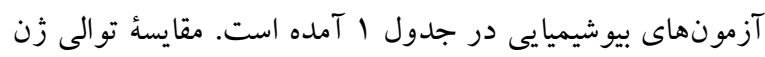
16S rDNA زن موردنظر موجود در NCBI تحتبررسى قرار كرفت. نتايج حاصل از تطبيق توالى و درخت فيلوزنتيكى نشان داد كه كونى دونه

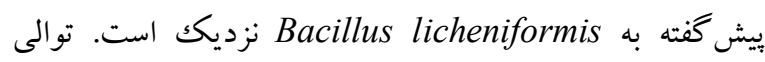
نو كلئوتيدى ارائهده در بانكك زنى NCBI با شئه شماره دسترسى MG192311 


$$
\text { جدول 1- آزمونهاى بيوشيميايى براى شناسايى سويههاى باكتريايى. }
$$

Table 1. Biochemical tests for identification of the bacterial strains.

\begin{tabular}{|c|c|c|c|c|c|c|c|c|c|}
\hline هيدروليز نشاسته (سانتى حاله حاز & TSI & سيترات & كاتالاز & هيدرو & هحيط كازئين-آنارئ در & محيط اسكيم-ميلكك آكار & КОН & رنكَآميزى كرم & باكترى \\
\hline$\cdot / r$ & ق قليا/قليا & - & + & - & - & - & - & باسيل و كرم مثبت & AT25 \\
\hline$\cdot / r$ & قليا /قليا & - & + & - & + & - & - & باسيل و گرمم مثبت & AT55 \\
\hline$\cdot / 1$ & قليا/اسيد & - & + & - & + & - & - & باسيل و كرم مثبت & AT56 \\
\hline$\cdot / r$ & قليا /قليا & - & + & - & + & - & - & باسيل و گرم مثبت & AT57 \\
\hline$\cdot \pi$ & قليا / قليا & - & + & - & + & - & - & باسيل و گرم مثبت & AT58 \\
\hline$\cdot / 9$ & اسيد/ قليا & - & + & - & + & - & - & باسيل و گرم مثبت & AT59 \\
\hline$\cdot / 1$ & قليا/ اسيد & - & + & - & + & - & - & باسيل و گرم مثبت & AT60 \\
\hline$\cdot / 1$ & قليا/ قليا & - & + & - & + & - & - & باسيل و گرم مثبت & AT61 \\
\hline$\cdot / 1$ & قليا /قليا & - & + & - & + & - & - & باسيل و رَم مثبت & AT62 \\
\hline$\cdot / r$ & اسيد/ قليا & - & + & - & - & - & - & باسيل و گرم مثبت & AT63 \\
\hline$\cdot / r$ & اسيد/اسيد & - & - & - & + & - & - & باسيل و گرم مثبت & AT64 \\
\hline$\cdot / 1$ & قليا/ اسيد & - & + & - & + & - & - & باسيل و گرم مثبت & AT65 \\
\hline$\cdot / 4$ & قليا /قليا & - & + & - & - & - & - & باسيل و كرم مثبت & AT66 \\
\hline$\cdot r$ & اسيد / قليا & - & - & - & + & - & - & باسيل و گرم مثبت & AT67 \\
\hline$\cdot / r$ & اسيد/اسيد & - & + & - & - & - & - & باسيل و كرم مثبت & AT68 \\
\hline
\end{tabular}

شكل ا- بررسى توليد آنزيم آلفآميلاز سوية متتخب با استفاده از آزمون هيدروليز نشاسته. (ايجاد هاله شفاف اطر اف ناحيه رشد باكترى نشان دهنده توليد آنزيم

$$
\text { آلفآميلاز و هيدروليز نشاسته است). }
$$

Fig. 1. Investigation of alpha-amylase production from the selected strain by using starch hydrolysis test. (Clear zone around bacterium growth indicates alpha-amylase production and starch hydrolyses).

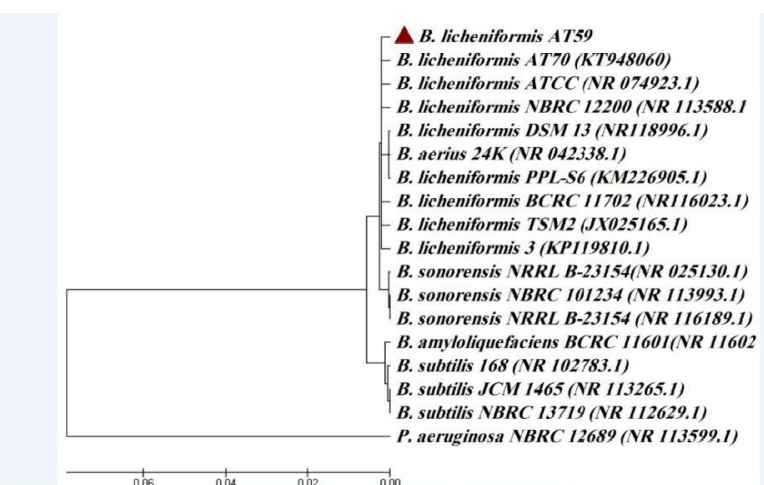

neighbor- شكل r- درخت فيلوزنى سوية باسيلوس لكنى فورميس AT59. سودموناس ايروزينا بعنوان گروه خارجى استفاده شد. درخت بر اساس روش

$$
\text { joining توليد شده و مقيايس ها بر اساس درصدى از هزار تكرار بيان شده است. }
$$

Fig. 2. The phylogenetic tree of Bacillus licheniformis AT59. P. aeruginosa NBRC 12689 was used as outgroup. The tree was generated using the neighbor-joining method. Bootstrap values expressed as percentages of 1000 replications. 


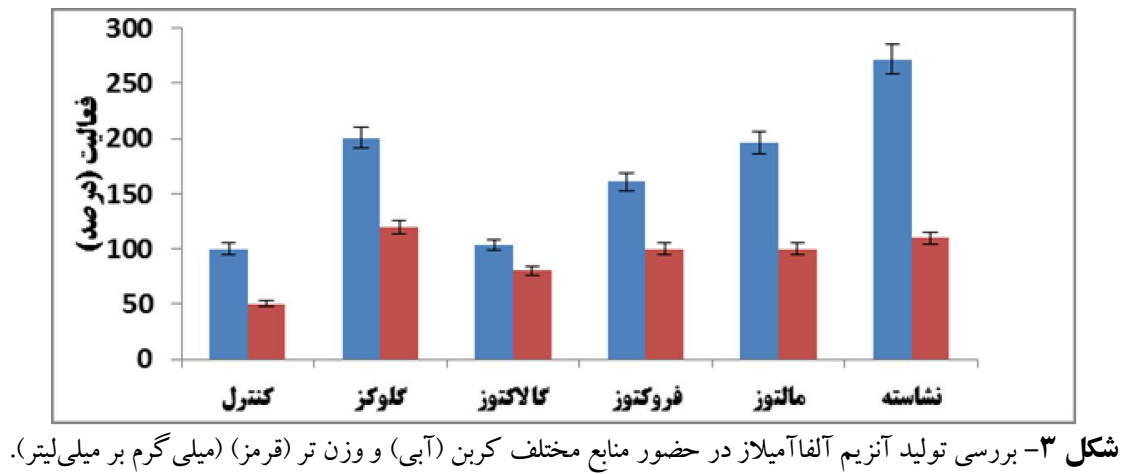

Fig. 3. Investigation of alpha-amylase production in different carbon sources (blue) and wet mass (red) (mg/ml)

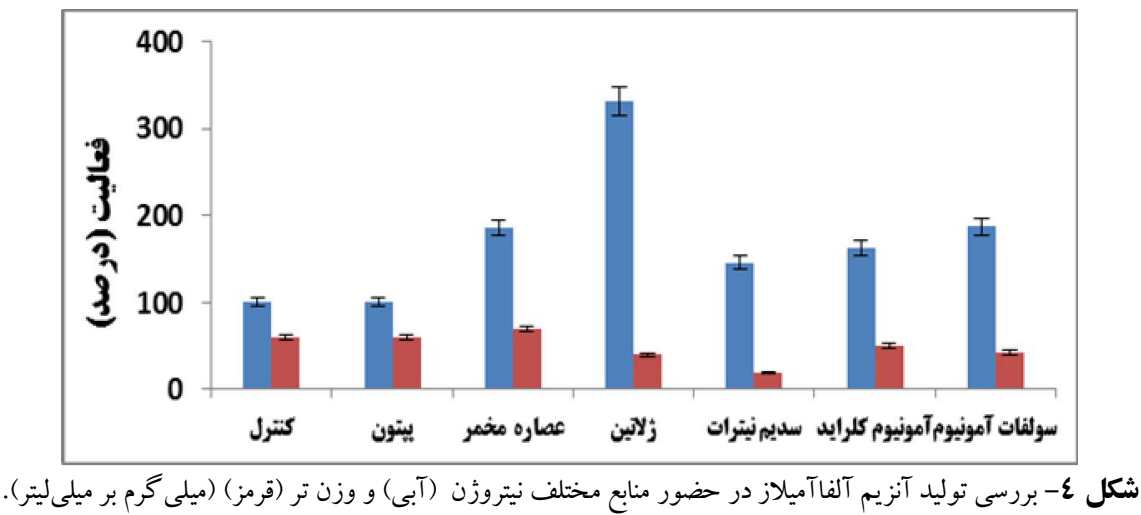

Fig. 4. Investigation of alpha-amylase production in various nitrogen sources (blue) and wet mass (red) (mg/ml).

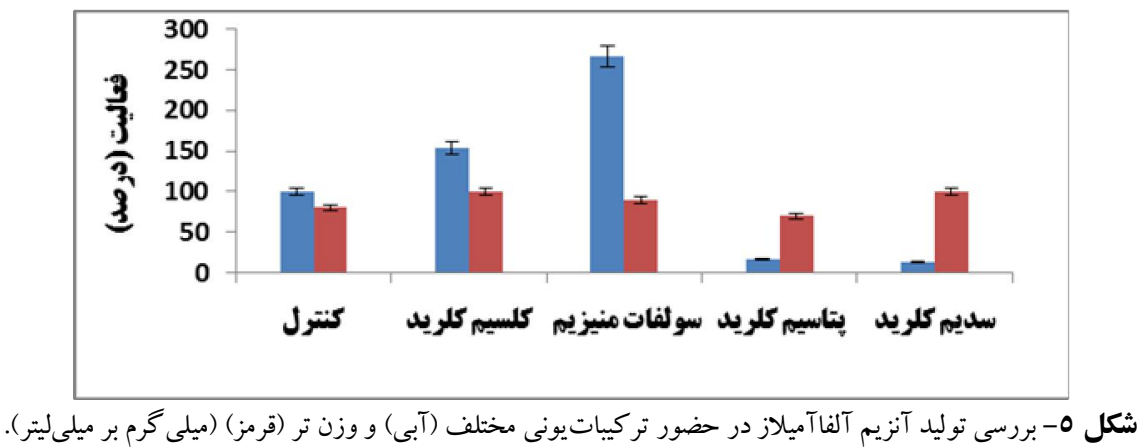

Fig. 5. Investigation of alpha-amylase production in various ion compounds (blue) and wet mass (red) (mg/ml).

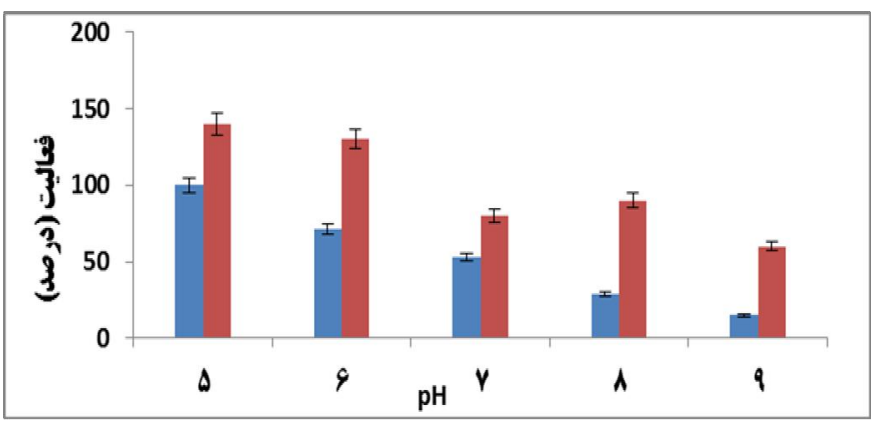

شكل 7هpH هاى مختلف (آبى) و وزن تر (قرمز) (ميلى خرم بر ميلىليتر).

Fig. 6. Investigation of alpha-amylase production in various pH (blue) and wet mass (red) (mg/ml). 
باكتريايى با خاصيت هيدروليز كندگى بالا از جشمه آب گرم

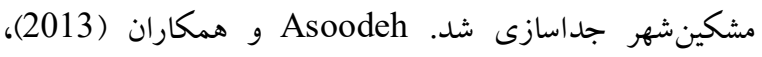
سويههاى باكتريايى مولد آلفآميلاز گرمادوست از جشمه آب

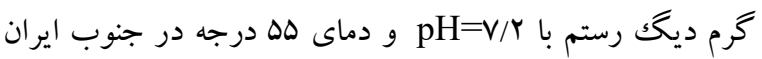

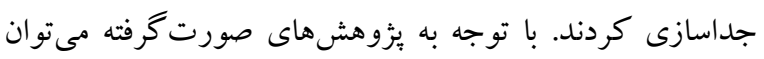

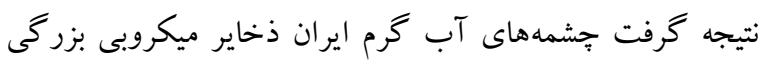

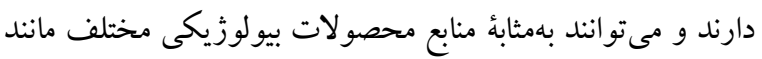

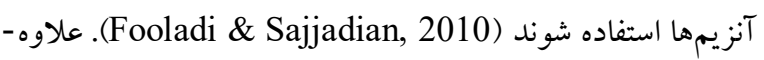

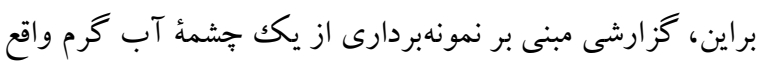
در هند جهت دستيابى به باكترىهاى مولد آلفآميلاز كرمادوست، به كوشش Sen و همكاران (2014) منتشر شده است.

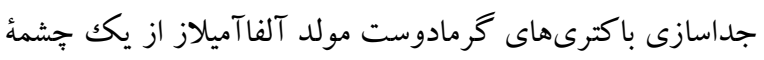
آب گرم واقع در تركيه صورت گرفته است ( Baysal et al.,

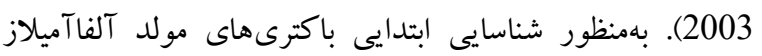

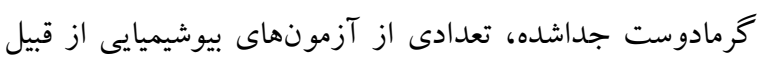

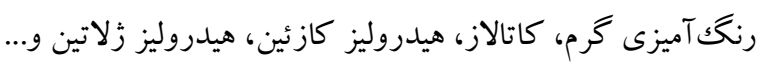

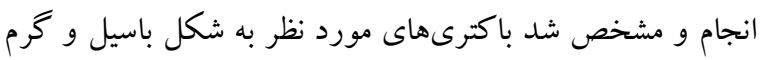
مثبت هستند. امروزه، توليد تجارى آلفآميلازها با استفاده از Pandey et al., ) اعضاى جنس باسيلوس صورت مى

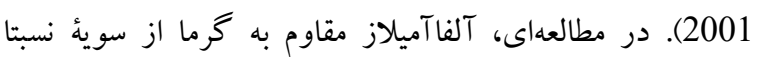
كرمادوست از Bacillus subtilis به نام Mahdavi .(Asgher et al., 2007) آميلازى با فعاليت دمايى وسيع را از سويهاى از cereus به نام GUF8 جداسازى و تعيين خصوصيت كريت كردند.

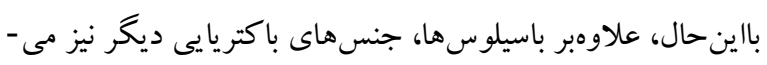

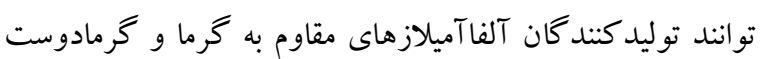

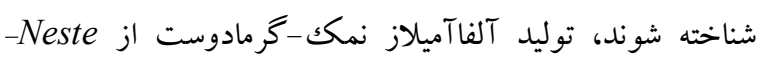

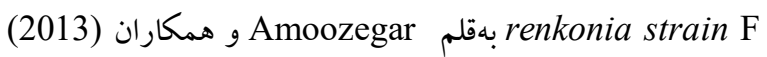
گزارش شد. ازجمله مهمترين عوامل اثر گذار بر متركم متابوليسم

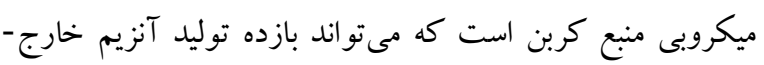

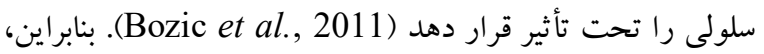
در اين بزوهش، بهمنظور دستيابى به محيط بهينه، توليد آنزيم

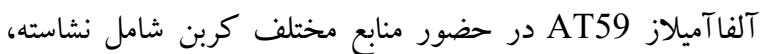

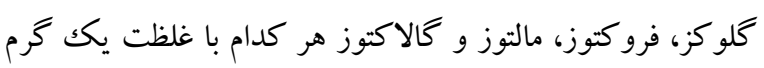
بر ليتر بررسى شد. نتايج نشان داد كه نشاسته مؤثرترين منبع در مر مرود
بـ بهتيب بيشترين و كمترين ميزان رشد را نشان داده است.

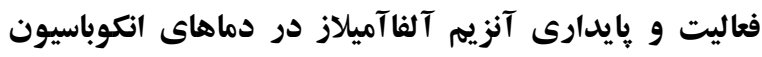
مختلف دما ازجمله مهمترين عوامل اثر گذار بر ساختار ذاتى يك آنزيم

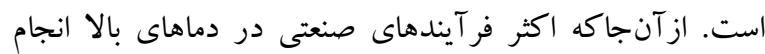

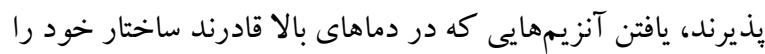

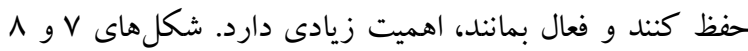

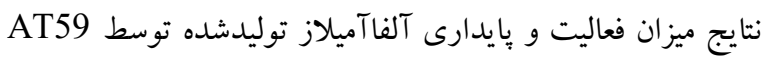
در دماهاى مختلف را نشان مىدهد. اين آنزيم در دماهاى مختلف

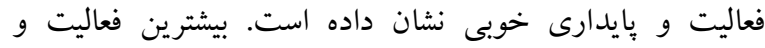

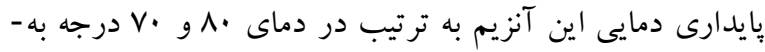

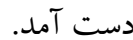
از آنجاكه اكثر فرايندهاى صنعتى معمولاً در دماهاى بالا انجام

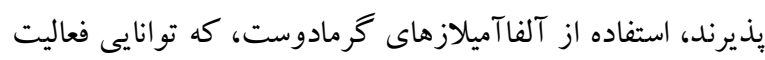
و حفظ ساختار خود در اين دماها را دارند، مى تو اند جهت بيشبرد هرجه بيشتر اين فرايندها كمكك كننده باشد (

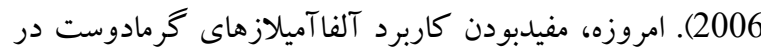
صنايع مختلف از جمله نساجى، فراورى مواد غذايى، مواد شوينده

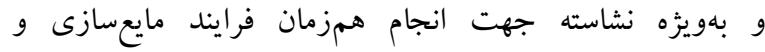
زلاتيناسيون نشاسته و كاهش هزينهاى خنكك كردن، اثبات شده Abdel-Fattah et al., 2012; Antranikian \& Egor-) است ova, 2007; Zeikus et al., 1998 جداسازى و غربال گرى باكترىهاى مولد آلفآميلاز گرمادوست،

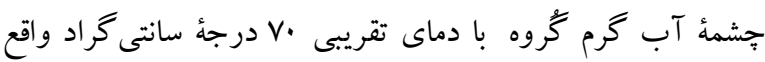

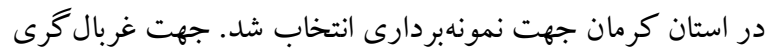
از محيط نشاسته-آكار استفاده شد و آزمون هيدروليز نشاسته انجام إنهام كرفت. كلنىهاى داراى هالة شفاف بهمنزلهُ سويههاى توليد كنندة

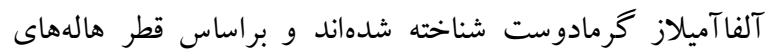

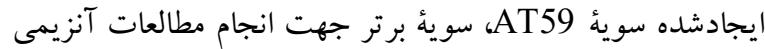
در نظر گرفته شد. بهور مشابه، در تحقيق Fooladi و Sajjadian (2010)، بهمنظور دستيابى به سويههاى مولد آلفا آميلاز مقاوم به

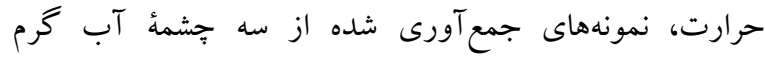
محلات، لاريجان و مشكين شهر تحت تحليل قرار گرفت و كلنى أنى 
بالاترين سطح توليد آلفآميلاز Nesterenkonia sp. F

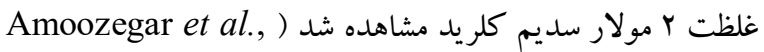
2013). در اين بثروش، بهمنظور تعيين pH بهينه براى توليد آنزيم

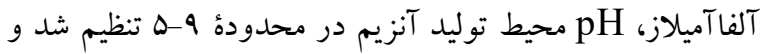

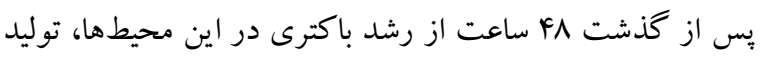

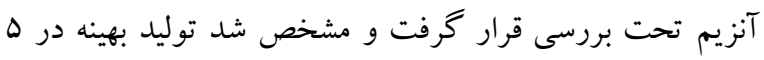
pH

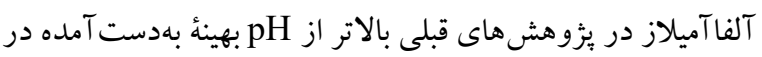

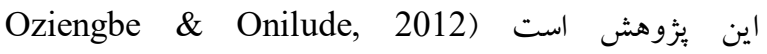
(Prakash et al., 2009; Amoozegar et al., 2013; فعاليت و پِايدارى دمايى آلفآميلاز AT59 نشان داد اين آنزيم

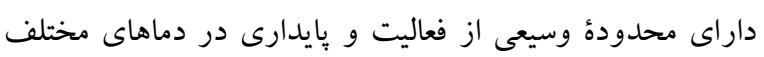

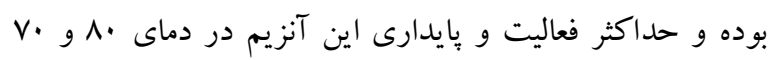

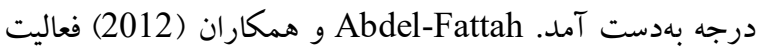
دمايى آلفآميلاز سويهاى از

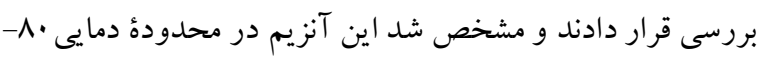

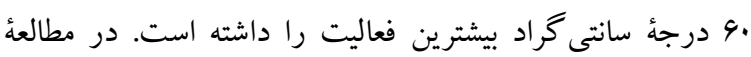

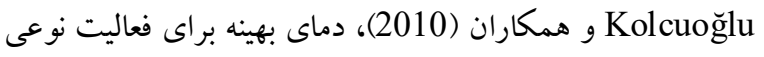

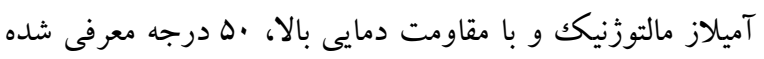

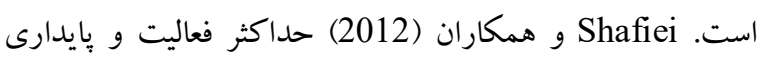
آلفآميلاز Nesterenkonia sp. F را بهترتيب در دماهاى هات

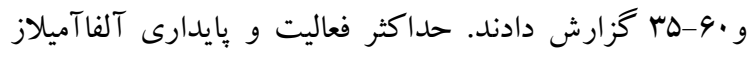

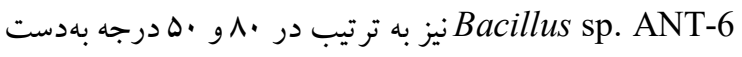

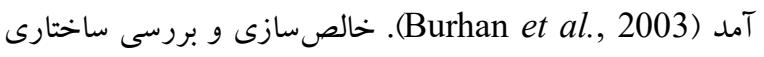

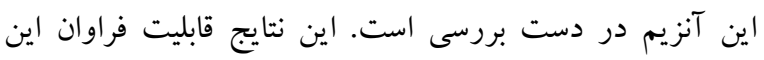
آنزيم را براى استفاده در صنايع نشان مىدهد.

\section{سياسگزارى}

نويسندكان مقاله از معاونت يزوهشى دانشكاه شهيد باهنر كرمان بهدليل حمايت مالى در انجام اين بروزه تشكر و قدردانى مى كنند.

\section{REFERENCES}

Abdel-Fattah, Y.R., Soliman, N.A., El-Toukhy, N.M., ElGendi, H. and Ahmed, R.S. 2012. Production, purification, and characterization of thermostable alpha-amylase produced by Bacillus licheniformis isolate AI20. - J. Chem. 13: 1-11.
توليد آنزيم بوده است. در بى يافنن محيط بهينه براى توليد

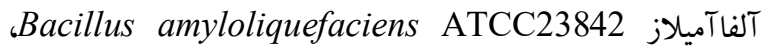
غلظتهاى Y-ه/• از منابع مختلف كربن شامل نشاسته محلول،

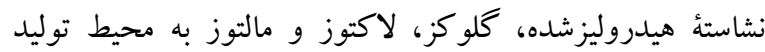

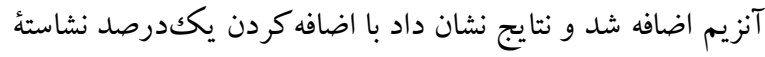

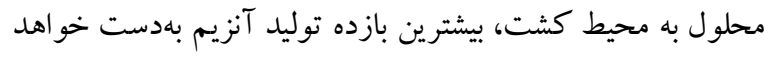

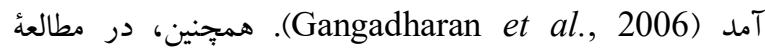
Amoozegar و همكاران (2013)، غلظت يككدرصد نشاسته غلظت بهينه براى توليد آلفآميلاز

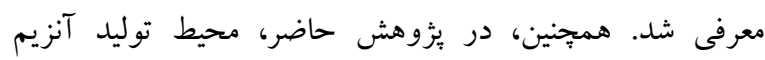

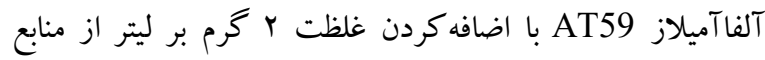

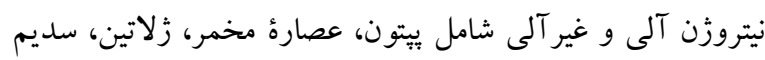

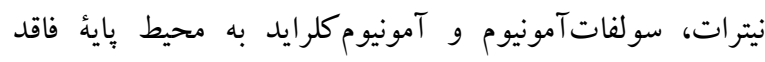

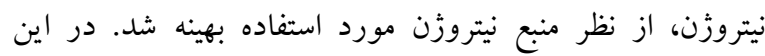

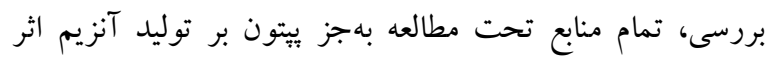

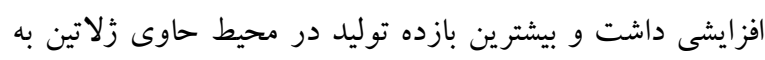
دست آمد. اين در حالى است كه در يزوهش و ي يتون بهترين منبع نيتروزن آلى Oziengbe براى توليد آلفآميلاز شناخته شد. بهينهسازى محيط توليد آنزيم سوية Nesterenkonia strain F در حضور منابع مختلف تولف نيتروزن با غلظتهاى مختلف صورت گرفت و مشخص شد سوية موردنظر در محيط حاوى VD/· درصد عصاره مخمر بيشترين ميزان آلفاآميلاز را توليد كرده است (Amoozegar et al., 2013). در اين بُزوهش، بررسى اثر يونهاى فلزى مختلف بر ميزان توليد

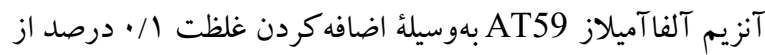

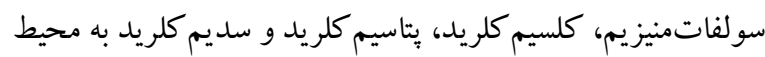

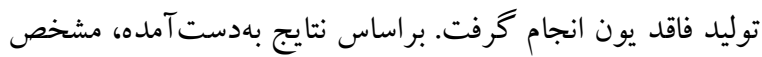

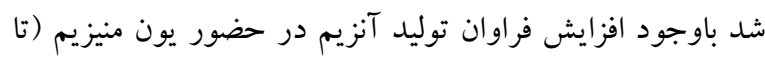

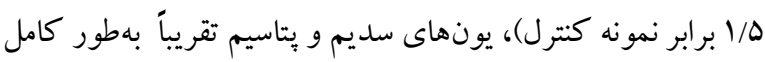

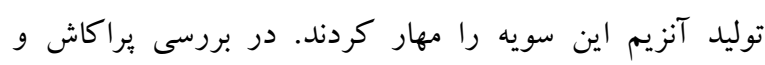

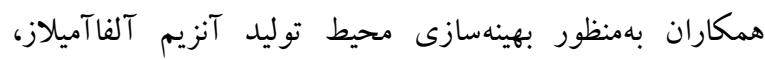

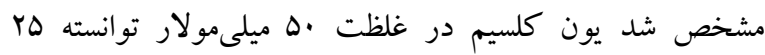

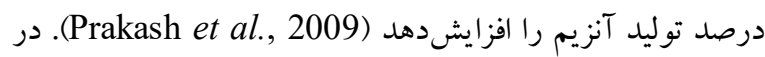
يكك مطالعه، سولفات منيزيم در غلظت يكك ميلىمولار منبع بهينه توليد آنزيم آلفآميلاز معرفى شد (Sodhi et al., 2005). 
Afrisham, S., Badoei-Dalfard, A., Namaki-Shoushtari, A. and Karami, Z. 2016. Characterization of a thermostable, $\mathrm{CaCl}_{2}$-activated and raw-starch hydrolyzing alpha-amylase from Bacillus licheniformis AT70: Production under solid statefermentation. - J. Mol. Catal. B: Enzym. 132: 98-106.

Ahmadi, A., Ghobadi, S., Khajeh, K., Nomanpour, B. and Badoei-Dalfard, A. 2010. Purification of $\alpha$ Amylase from Bacillus sp. GHA1 and its partial characterization. - J. Iran Chem. Soc. 7: 432-440.

Aiyer, P.D. 2005. Effect of C: N ratio on alpha-amylase production by Bacillus licheniformis SPT 27. African J. Biotech. 3: 519-522.

Amoozegar, M.A., Samareh-Abolhasani, B., Shafiei, M., Didari, M. and Hamedi, J. 2013. Production of halothermotolerant alpha-amylase from a moderately halophilic bacterium, Nesterenkonia Strain F. Progress in Biological Sciences. 2: 85-97.

Antranikian, G. and Egorova, K. 2007. Extremophiles, a unique resource of biocatalysts for industrial biotechnology. Extremophiles. - ASM Press, Washington 361-406.

Asgher, M., Asad, M.J., Rahman, S.U. and Legge, R.L. 2007. A thermostable $\alpha$-amylase from a moderately thermophilic Bacillus subtilis strain for starch processing. - J. Food Eng. 79: 950-955.

Asoodeh, A., Alemi, A., Heydari, A. and Akbari, J. 2013. Purification and biochemical characterization of an acidophilic amylase from a newly isolated Bacillus sp. DR90. - Extremophiles 17: 339-348.

Aullybux, A.A. and Puchooa, D. 2013. Alpha-amylase production on low-cost substrates by Naxibacter $\mathrm{sp}$. isolated from Mauritian soils. - Br. Microbiol. Res. J. 3: 478-491.

Azadian, F., Badoei-Dalfard, A., Namaki-Shoushtari, A. and Hassanshahian, M. 2016. Purification and biochemical properties of a thermostable, haloalkaline cellulase from Bacillus licheniformis AMF-07 and its application for hydrolysis of different cellulosic substrates to bioethanol production. - Mol. Bio. Res. Comm. 5: 143-155.

Babu, K.R. and Satyanarayana, T. 1995. Alpha-amylase production by thermophilic Bacillus coagulans in solid state fermentation. - Process Biochem. 30: 305309.

Badoei-Dalfard, A., Karami, Z., Ramezani-Pour, N. 2016. Bench scale production of nicotinic acid using a newly isolated Stenotrophomonas maltophilia AC21 producing highly-inducible and versatile nitrilase. - J. Mol. Catal. B: Enzym. 133: 552-559.

Badoei-Dalfard, A., Karami, Z., Ramezani-pour, N. 2016. Production and characterization of a nitrilase from Pseudomonas aeruginosa RZ44 and its potential for nitrile biotransformation. - Iranian J. Biotechnol. 14: 142-153.

Baysal, Z., Uyar, F. and Aytekin, Ç. 2003. Solid state fermentation for production of alpha-amylase by a thermotolerant Bacillus subtilis from hot-spring water. - Process Biochem. 38: 1665-1668.

Bernfeld, P. 1955. Amylases, $\alpha$ and $\beta$. - Methods Enzymol. 1: 149-158.
Bouzas, T.M., Barros-Velázquez, J. and Gonzalez Villa, T. 2006. Industrial applications of hyperthermophilic enzymes: a review. - Protein Pept. Lett. 13: 645-651.

Bozic, N., Ruiz, J., Santin, J., and Vujcic, Z. 2011. Optimization of the growth and alpha-amylase production of Bacillus subtilis IP 5832 in shake flask and laboratory fermenter batch cultures. - J. Serb. Chem. Soc. 76: 965-972.

Burhan, A., Nisa, U., Gökhan, C., Ömer, C., Ashabil, A., and Osman, G. 2003. Enzymatic properties of a novel thermostable, thermophilic, alkaline and chelator resistant amylase from an alkaliphilic Bacillus sp. isolate ANT-6. - Process Biochem. 38: 13971403.

Chandra, M.S., Mallaiah, K.V., Sreenivasulu, P. and Choi, Y.L. 2010. Purification and characterization of highly thermostable alpha-amylase from thermophilic Alicyclobacillus acidocaldarius. Biotechnol. Bioprocess Eng. 15: 435-440.

Fooladi, J. and Sajjadian, A. 2010. Screening the thermophilic and hyperthermophilic bacterial population of three Iranian hot-springs to detect the thermostable alpha-amylase producing strain. - Iran J. Med. Microbiol. 2: 46-50.

Gangadharan, D., Sivaramakrishnan, S., Nampoothiri, K.M. and Pandey, A. 2006. Solid culturing of Bacillus amyloliquefaciens for alpha-amylase production. - Food Technol. Biotechnol. 44: 269-274.

Haki, G.D. and Rakshit, S.K. 2003. Developments in industrially important thermostable enzymes: a review. - Bioresour. Technol. 89: 17-34.

Karakaş, B., İnan, M. and Certel, M. 2010. Expression and characterization of Bacillus subtilis PY22 alphaamylase in Pichia pastoris. - J. Mol. Catal. B: Enzym. 64: 129-134.

Kolcuoğlu, Y., Colak, A., Faiz, O. and Belduz, A.O. 2010. Cloning, expression and characterization of highly thermo-and $\mathrm{pH}$-stable maltogenic amylase from a thermophilic bacterium Geobacillus caldoxylosilyticus TK4. - Process Biochem. 45: 821-828.

Kristjanson K.J. 1989. Thermophilic organisms as source of thermostable enzymes. - Trends Biotechnol. 7: 49-53.

Mahdavi, A., Hassan Sajedi, R., Rassa, M. and Jafarian, V. 2010. Characterization of an alpha-amylase with broad temperature activity from an acid-neutralizing Bacillus cereus strain. - Iran J. Biotechnol. 8: 103111.

Miller, G.L. 1959. Use of dinitrosalicylic acid reagent for determination of reducing sugar. - Anal. Chem. 31: 426-428.

Oziengbe, E.O. and Onilude, A.A. 2012. Production of a thermostable alpha-amylase and its assay using Bacillus licheniformis isolated from excavated land sites in Ibadan, Nigeria. - Bayero Journal of Pure and Applied Sciences 5: 132-138.

Pandey, A., Soccol, C.R., Rodriguez-Leon, J.A. and Nigam, P. 2001. Solid state fermentation in biotechnolog'y. - J. Microbiol. Methods 34: 405-423.

Prakash, B., Vidyasagar, M., Madhukumar, M.S., Muralikrishna, G. and Sreeramulu, K. 2009. Produ- 
ction, purification, and characterization of two extremely halotolerant, thermostable, and alkalistable apha-amylases from Chromohalobacter sp. TVSP 101. - Process Biochem. 44: 210-215.

Ramachandran, S., Patel, A.K., Nampoothiri, K.M., Francis, F., Nagy, V., Szakacs, G. and Pandey, A. 2004. Coconut oil cake-a potential raw material for the production of alpha-amylase. - Bioresour. Technol. 93: 169-174.

Ramezani-Pour, N., Badoei-Dalfard, A., Namaki-Shoushtari, A. and Karami, Z. 2015. Nitrile-metabolizing potential of Bacillus cereus strain FA12; Nitrilase production, purification, and characterization. - Biocatal. Biotransform. 33: 156-166

Samie, N., Noghabi, K.A., Gharegozloo, Z., Zahiri, H.S., Ahmadian, G., Sharafi, H., Behrozi, R. and Vali, H. 2012. Psychrophilic alpha-amylase from Aeromonas veronii NS07 isolated from farm soils. - Process Biochem. 47: 1381-1387.

Sen, S.K., Raut, S., Satpathy, S., Rout, P.R., Bandyopadhyay, B. and Mohapatra, P.K.D. 2014. Characterizing novel thermophilic amylase producing bacteria from Taptapani hot spring, Odisha, India. Jundishapur. J. Microbiol. 7: 1-7.

Shafiei, M., Ziaee, A.A. and Amoozegar, M.A. 2012. Purification and characterization of a halophilic alpha-amylase with increased activity in the presence of organic solvents from the moderately halophilic Nesterenkonia sp. strain F. - Extremophiles 16: 627635.

Sneath, P.H.A., Mair, N.S., Sharpe, M.E. and Holt, J.G. 1986. Bergy's manual of systematic bacteriology, Vol. 2. - William and Wilkins, Baltimore, USA.

Sodhi, H.K., Sharma, K., Gupta, J.K. and Soni, S.K. 2005. Production of a thermostable alpha-amylase from Bacillus sp. PS-7 by solid state fermentation and its synergistic use in the hydrolysis of malt starch for alcohol production. - Process Biochem. 40: 525534.

Souza, P.M.D. 2010. Application of microbial alphaamylase in industry-a review. - Braz. J. Microbiol. 41: 850-861.

Tamura, K., Dudley, J., Nei, M. and Kumar, S. 2007. MEGA4: Molecular evolutionary genetics analysis (MEGA) software version 4.0. - Mol. Biol. Evol. 24: 1596-1599.

Zeikus, J.G., Vieille, C. and Savchenko, A. 1998. Thermozymes: biotechnology and structure-function relationships. - Extremophiles 2: 179-183.

How to cite this article:
Afrisham, S., Badoei-Dalfard, A., Namaki-Shoushtari, A., Karami, Z. and Malekabadi, S. 2018. Isolation and Identification of Bacillus producing thermophilic alpha amylase: production optimization and investigation of the activity and stability of enzyme. - Nova Biologica Rep. 4: 288-298.

افريشم، س.، بدويىدلفارد، ا.، نمكىشوشترى، ع.، كرمى، ز. و ملك آبادى،

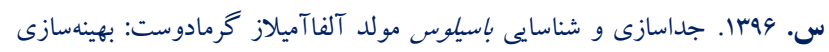

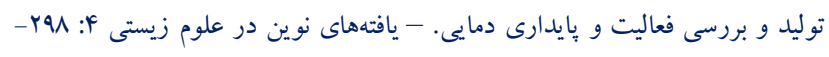

